\title{
PROCEEDINGS OF THE SIXTH SUMMER MEETING, HELD AT BROOKLYN, NEW YORK, AUGUST 14 AND 15, 1894
}

\author{
Herman Le Roy Fairchild, Secretary
}

CONTENTS

Sesgion of Tuese

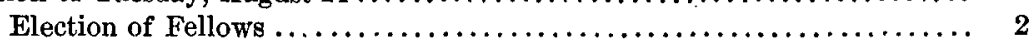

The nickel mine at Lancaster Gap, Pennsylvania, and the pyrrhotite deposit at Anthony's Nose, on the Hudson [abstract] ; by J. F. Kemp.. 3

A connection between the chemical and optical properties of amphiboles [abstract]; by Alfred C. Lane........................ 3

On a basic rock derived from granite [abstract]; by C. H. Smyth, Jr... 4

Dislocations in certain portions of the Atlantic coastal plain strata and their probable causes [abstract; discussion by N. S. Shaler] ; by Arthur Hollick.

Glacial origin of channels on drumlins; by George $\mathrm{H}$ Barton........... 5

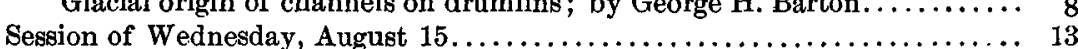

Report of the Mount Rainier Pacific Forest Reserve Committee........ 13

Proposed amendments to the constitution $\ldots \ldots \ldots \ldots \ldots \ldots \ldots \ldots \ldots . \ldots 15$

Proposed amendment to the by-laws ........................ 15

Tertiary and early Quaternary baseleveling in Minnesota, Manitoba and northwestward [abstract]; by Warren Upham .............. 17

Departure of the ice-sheet from the Laurentian lakes [abstract]; by Warren Upham.................................... 21

Note on Florentino Ameghino's latest paper on Patagonian paleontology ; by W. B. Scott................................. 28

Register of the Brooklyn summer meeting...................... 28

\section{Session of Tuesday, August 14}

The Society convened in room 11, second floor of the Packer Institute. In the absence of the President, Vice-President N. S. Shaler presided during the several sessions of the meeting. After the call to order, at 10 o'clock a $\mathrm{m}$, the acting President spoke a few words of salutation, and announced the death of two Fellows, Professor George H. Williams, of Baltimore, and Mr Amos Bowman, of Anacortes, Washington. 
The Secretary announced the result of the balloting for Fellows, as canvassed by the Council, as follows:

\section{Fellows Elected}

Miss Florence Bascom, A. M., B. S., Ph. D., Columbus, Ohio. Instructor in Geology, Petrography and Mineralogy in the Ohio State University.

Richard Charles Hills, Denver, Colorado. Mining Engineer.

Elfrrc Drew Ingall, Geological Survey Department, Ottawa, Canada. Mining

Engineer. In charge of Division of Mineral Statistics and Mines.

RoBert Tracy J JCKSON, S. B., S. D., 33 Gloucester street, Boston. Instructor in Paleontology, Harvard University.

David F. Lincoln, M. D., Geneva, New York.

Charles Joserh Nowwood, Frankfort. Kentucky. State Geologist and State Mine Inspector of Kentucky.

Charles Palache, B. S., Ph. D., Berkeley, California. Fellow in Geology in University of California.

Lours Valdentine Pirsson, Ph. B., New Haven, Connecticut. Instructor in Geology and Petrography in Sheffield Scientific School, Yale University.

Henry Lloyd Sмyтh, A. B., Cambridge, Massachusetts. Instructor in Mining Geology and Geological Surveying in Harvard University.

Lewis G.IRDNar W

William Smith Yeates, A. B., A. M., Atlanta, Georgia. State Geologist of Georgia.

$\Lambda$ communication from the Royal Society of London was read by the President, which referred to coöperation and aid in the matter of publishing the "Catalogue of Periodical Scientific Literature." It was voted, after some discussion and amendments, to appoint a committee of three, the acting President as chairman, to consider the matter of the communication and report at the winter meeting. The committee as named consists of N. S. Shaler, H. S. Williams and W J McGee.

The Secretary announced that the Council desired to apply the rule regarding the presentation of papers whose authors were absent that was applied at the preceding winter meeting. The rule is as follows:

"The Council rules that papers whose authors are not present when the title is called shall go to the end of the program unless the Society by special vote in each case decides otherwise."

The Secretary stated that the titles in the printed program had been arranged according to the classification given in the last report of the Council (volume 5, page 613), and that it was proposed to adhere to this order in the programs of future meetings; also to place at the head of the list the titles in that department of geology which had been at the foot of the list the preceding meeting, thus bringing all the several groups 
in rotation, during successive meetings, to the head of the program. The adoption of this rule will enable the Fellows to determine beforehand the relative position of their papers in the program. In accordance with this plan, the papers on petrography and mineralogy at this meeting headed the list.

The reading of papers was declared in order, and the first title announced was as follows :

THE NICKEL MINE AT LA NCASTER GAP, PENNSYLVANIA, AND THE PYRRHOTITE DEPOSIT AT ANTHONY'S NOSE, ON THE HUDSON

\author{
BY J. F. KEMP
}

\title{
[Abstract $]$
}

The paper described, with maps, sections, lantern views and specimens, these two deposits of nickeliferous pyrrhotite. The former is on the contact between a great intruded lens of some original, basic, intrusive rock-now altered to a mass of coarsely crystalline, green hornblende (i.e., it is an amphibolite)-and its walls of mica-schist and pegmatite. The latter is a lens or pod of the type familiar in the iron mines of the highlands of New York and New Jersey, and is in acidic gneiss of the oomposition ef granite. The question of origin was discussed with especial reference to magmatic separation, and with comparisons with nickel ores elsewhere in America and in Norway.

Remarks were made by Alfred C. Lane, W. N. Rice and Frank D. Adams.

This paper will be printed in full in the Transactions of the American Institute of Mining Engineers, Bridgeport meeting, October, 1894.

The second paper was-

\section{A CONNECTION BETWEEN THE CHEMICAL AND OPTICAL PROPERTIES OF AMPHIBOLES}

BY ALFRED C. LANE

\section{[Abstract]}

The following law secms to apply to all the hornblendes, so far as the data go, with one exception :

The amount of $\mathrm{Na}_{2} \mathrm{O}$ contained $=90 / 17(0.012-$ (the birefraction of the orthopinacoidal section) ), said birefraction being considered + or - according as the eharacter of the extinction is + or - .

The data are limited t the constants only approximate. It is therefore very desirable that those making hornblende analyses should also measure this birefraction. It also remains to be seen how far this law holds, for it cannot be expected to be true throughout the group.

In the absence of the author, the third paper was held in its place by vote, and it was read by J. F. Kemp. 
ON A BASIC ROCK DERIVED FROM GRANITE

BY C. H. SMYTH, JR.

\section{[Abstract $]$}

Intimately associated with the hematite of the Old Sterling mine, Jefferson county, New York, is a dark, rather massive rock, which was described by E. Emmons as serpentine and has always been referred to as such. Some portions of the rock closely resemble serpentines, but most of it contains numerous irregular grains of quartz. The field relations are those of intrusive rock, but the abundant quartz indicates that it could hardly be of the basic character usually found in rocks which alter to serpentine. The true nature of the original rock is shown by a few limited areas which have suffered comparatively little change. These cores of unchanged rock are but a few yards in extent and consist of a reddish coarsegrained granite composed chiefly of quartz and feldspar. This granite, evidently very acid, shades gradually into the surrounding dark colored rock of serpentinous aspect. Under the microscope this change is seen to result from the gradual replacement of the feldspar, and to a less degree of quartz by an aggregate of minute green or yellow scales. Every stage of the process is shown from a slight alteration of feldspar to a complete replacement of all of the constituents of the granite by the green aggregate. As to the mineralogic affinities of the aggregate it seems more closely related to the chlorites than any other minerals, and is quite different from serpentine. Chemical analysis of a completely altered specimen shows about 30 per cent of $\mathrm{SiO}_{2}, 12$ per cent of $\mathrm{H}_{2} \mathrm{O}, 11$ per cent of $\mathrm{MgO}$, and 27 per cent of $\mathrm{FeO}$. These figures show a great amount of change from the original acid granite and point to chemical rather than mechanical agents as the chief factor in the process. The rock is considerably crushed, but it is probable that this acted chiefly in giving access to the solutions causing the alteration, as dynamo-metamorphism alone does not usually change the bulk composition of a rock so greatly. From the large amount of iron in the rock, together with the fact that similar rocks occur at all the iron mines, but nowhere else in the vicinity, it seems reasonable to infer that there is a causal connection between the iron ore and the altered granite. Several facts indicate that the ore is a replacement of limestone, probably through the action of solutions derived from oxidizing pyrites near at hand. Such solutions, together with those resulting from the dissolving of the limestone, would afford just the sort of agent required to effect the profound change shown in the granite.

Remarks were made upon the paper by Jed Hotchkiss.

The next paper was-

A STUDY OF THE CHERTS OF MISSOURI

BY EDMUND O. HOVEY

H. S. Williams and N.S. Shaler made remarks upon the matter of the paper, which is printed in the American Journal of Science for November, 1894, vol. xlviii, pp. 401-409. 
Passing several papers whose authors were absent, the next paper presented was-

DISLOCATIONS IN CERTAIN PORTIONS OF THE ATLANTIC COASTAL PLAIN STRATA AND THEIR PROBABLE CA USES*

BY ARTHUR HOLLICK

\section{[Abstract]}

Extending from Nantucket, Marthas Vineyard, through Block island, Gardiners island, Long island, Staten island and northern New Jersey, there is a clearly marked line or area of disturbance which presents many features entirely different from those with which we are familiar elsewhere. A portion has been considered by Professor N. S. Shaler to represent mountain-making effects, while the writer is satisfied that ice action has produced similar phenomena.

From a careful study of the region as a whole, we are now in a position to state, as beyond question, that this line of disturbance is coincident with the line of the terminal moraine from Nantucket to northern New Jersey ; that the phenomena of folding and crumpling in the Cretaceous and post-Cretaceous strata are only to be found where the moraine has advanced over some portion of the former coastal plain, and that these phenomena cease abruptly where the moraine bends away from or finally leaves the plain.

The writer is of the opinion that one series of cause of effect has been instrumental throughout, and the question at issue seems to be which of the two theories just referred to is supported by the greater weight of evidence.

Beginning with Marthas Vineyard, we may consider the general structure there as typical of the region elsewhere. The island consists essentially of a series of hills in the north, composed of a core of Cretaceous and post-Cretaceous strata, tilted and folded, flanked on the north and capped on the top by bowlder till which gradually merges into water-assorted material on the sonthern flanks and extends over the plains beyond. The Gay rread escarpment is the most extensive section across the line of disturbance which is anywhere exposed to view.

Proceeding westward, we find a similar structure to exist on Long island, although the exposures are far more limited, but it is only necessary to imagine Long island separated into parts by convenient north and south erosion channel, in order to reproduce Gay Head indefinitely.

On Staten island the facts are even of greater significance and interest. The moraine crosses a portion of the coastal plain near the Narrows, thence bends northward, rests on the Archean axis, and again enters upon the plain a few miles further west. Throughout both portions of the moraine where it rests on the coastal plain evidences of dislocation and distortion are to be seen. Between these portions there is not the slightest indication of any disturbance and the topography of the plain is level and uniform. This little area seems to have been specially preserved as an object-lesson in this connection.

In northern New Jersey the evidences of disturbance are not so manifest, which may perhaps be accounted for on the supposition that the ice, having advanced over this portion of the plain from a comparatively level area, did not plow down

* The paper was illustrated by charts and maps of the region under discussion and by sketches of many of the localities mentioned. 
to the depth which it did in the case of Long Island sound, where the advance was over a hard rock escarpment.

As to the dip and strike of the disturbed strata they are found to be too erratic to be of much stratigraphic value, but there is a prevailing strike coinciding with the trend of the moraine, and the strata are either bent into overthrust folds or tilted, with the dip toward the north. North and south anticlines are also met with. At the sides of the harbors on the north shore of long island the dip is often east or west, apparently due to lateral squeeze or thrust.

There seems to be but little question as to the competency of ice to produce the phenomena in question, and in this connection the recent experiments by $\mathrm{Mr}$ Bailey Willis* are especially apropos.

As favoring the theory of ice action we therefore have the general structure of the morainal region of the coastal plain; the uniform coincidence of distorted coastal plain strata with the line of the moraine; the absence of any distortions where the moraine does not reach the plain ; the much more pronounced distortions where the moraine indicates an extensive advance of the ice over the plain, and the prevailing directions of dip and strike.

The only element which enters into the theory of mountain-making forces as the probable agency which is not also an argument for the ice theory is that of geologic age. The topography of the Marthas Vineyard hills is considered by Professor Shaler to be preglacial. If this be the fact, then the phenomena of dislocation in Marthas Vineyard must be considered as isolated from the remainder of the region and as due to a different cause. The writer failed to see the evidence of it, and it is certainly not the case elsewhere. Thus we find beds of "yellow gravel," the equivalent of the Lafayette formation, included as part of the distorted strata, showing that the disturbance took place subsequent to the period when these gravels were laid down. All authorities are now practically agreed that this formation is at least as recent as the Pliocene, and, considering this fact alone, we should have a very brief period of time in which to develop any preglacial topography. It would imply a very great stress, suddenly and violently discharged-almost in the nature of an eruption in fact-and not a gradual mountain-making process. So far as my experience goes, the facts do not warrant us in assuming that such conditions have prevailed.

Finally, any such development of force would result in the disturbance of strata far below the surface, as well as above, and this we do not find to be the case. As a single example, we may take the exposure at Cold Spring, Long island, where the superficial strata are beautifully folded and crumpled, while the lower ones below the area of ice action are undisturbed. The significant fact should also be remembered that the line of disturbance extends in a generally east and west directions instead of north and south-the direction in which experience and observation would lead us to expect that mountain-making forces in this region would be manifested.

On the other hand, the theory of ice action in connection with the continental glacier of the Ice age seems to be both a rational and an adequate one. The facts are in harmony with it; it enables us to consider the entire area of disturbance as a comprehensive whole, with one series of cause and effect throughout, and not as

*"The Mechanics of Appalachian Structure," extract from the Thirteenth Ann. Rept. of the U.S. Geol. Survey, 1891-'92, pp. 217-281. 
a number of isolated districts in which identical phenomena are to be accounted for on different hypotheses. It is also a theory which nothing in our previous observation or experience would cause us to doubt, and is one which has been applied to similar phenomena in Europe, especially in the islands of Moën and Rugen, in Denmark.

\title{
In discussing Mr Hollick's paper Acting President Shaler said:
}

My objections to Mr Hollick's paper may be summed up as follows: On the western end of the island of Marthas Vineyard, a region which Mr Hollick has not personally examined, series of Cretaceous and Tertiary rocks, baving an aggregate thickness of several hundred feet, are folded into extended anticlinals and synclinals, the average dips of which exceed $40^{\circ}$ of declivity. The width of this area of folded rocks is not less than five miles, extending entirely across the island. The average amplitude of the folds probably exceeds one thousand feet. The amount of the disturbance is as great on the southern side of the island, the region furthest removed from the main ice front, as it is on the northern side of the field. Moreover, the axes of the folds are not at right angles to the path of the glacial movement, but in a general way parallel to that course.

On this field of profoundly dislocated rocks there remains in an almost unaltered state the complicated erosion topography which existed when the region was in. vaded by the ice of the last glacial period. Considerable areas are destitute of erratic material. Scarcely any of the valleys have been so far obstructed by the drift that their forms are not readily distinguishable. Moreover, on the northern or shock side of the island there are many minor disturbances of the strata which may be reasonably attributed to the thrusting of the ice-sheet, but these dislocations greatly differ from the broad folds which characterize the other parts of the district. They seem to me to be imposed upon the preglacial topography.

For the reasons I have indicated, as well as for others which cannot be briefly stated, while granting that the horizontal thrusting of an ice-sheet may disrupt strata, I do not believe that the foldings of the Marthas Vineyard section are due to this cause.

\section{Mr Hollick replied:}

Professor Shaler is in error in regard to my not having personally visited and examined the western end of the island. The question seems to resolve itself into merely a difference of opinion as to the preglacial age of the topography.

It was voted to adjourn the further discussion until after the noon recess.

Upon reassembling at 2.15 o'clock p m J. W. Spencer spoke upon $\mathrm{Mr}$ Hollick's paper.

The first paper read was entitled-

\section{RECONSTRUCTION OF THE ANTILIEAN CONTINENT}

\author{
BY J. W. SPENCER
}

Remarks upon this paper were made by W. B. Scott as to the Antillean faunas and their bearing upon the former land connection; by $\mathrm{J}$. 
J. Stevenson upon the latter point, and by W J McGee. 'The paper is printed in later pages of this volume.

The next paper was-

EVIDENCES AS TO THE CHANGE OF SEA LEVEL

BY N. S. SHALER

Remarks were made by J. W. Spencer, Joseph Le Conte, A. C. Lane and the acting President. The paper is printed in full in this volume.

The following paper was read:

EXTENSION OF UNIFORMITARIANISM TO DEFORMATION

BY W J MCGEE

The paper was discussed by N. S. Shaler, Joseph Le Conte, R. P. Whitfield, F. D. Adams and J. W. Spencer. The paper is printed in full in this volume.

Passing over several papers whose authors were absent, the next paper was-

DRUMLINS IN THE VICINITY OF GENLVA, NEW YORK

BY D. F. LINCOLN

Remarks upon the paper were made by George H. Barton.

The following paper was presented:

GLACIAL ORIGIN OF CHANNELS ON DRUMLINS*

BY GEORGE H. BARTON

Contents

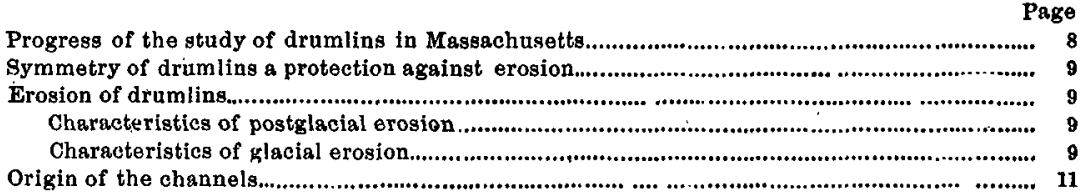

Progregs of the Study of Drumlins in Massachusetts

In connection with the work of the United States Geological Survey and under the direction of Professor N. S. Shaler nearly eighteen hundred drumlins have been mapped and studied in Massachusetts. The time allowed in which to cover so large

* Published by permission of the Director of the United States Geological Snrvey. 
an area as the whole state has permitted only a general reconnaissance, rather than a detailed survey, and much more time is required to produce a well finished result.

\section{Symmetry of Drụmlins a Protection against Erosion}

The typical drumlin or lenticular hill of Hitchcock, with its smooth, flowing outlines, long, gentle slopes on the ends, and somewhat steeper slopes on the sides, and with no break in its curves, is the most symmetrical and graceful hill that nature produces. This very perfection of symmetry in form has enabled it to withstand the attacks of the rains and snows by causing the water to flow off with an even distribution, and thus preventing it from collecting in sufficient quantities to produce an incipient crease, which in time might be enlarged to a small gully and stream channel. The small amount of erosion that has taken place has been so evenly distributed over the whole surface that it is now practically impossible to even make an approximate estimate of its amount.

\section{Erosion of DrumLins}

CHARACTERISTIOS OF POSTGLACIAL GROSION

But the single typical drumlin is not the only form. There are groups of two, three or more, each member of which is nearly or quite perfect in itself and oniy touching its neighbor at its lowest periphery. In such cases the valley between has its bottom nearly or quite on a level with that of the surrounding country. In other cases the members of a group may be so closely joined together as to rise from the same base and have a quarter or a third of their mass in common, and then the bottom of the valley between is at an elevation far above the surrounding country level-an elevation one-third, one-half or two-thirds that of the summits on each side, but in all these cases the valley is one of construction, and its origin is in common with that of the drumlins themselves. Rain-water flowing down the adjacent slopes accumulates in these valleys in little streams, which erode small channels from either end of the valley to the base of the group. These features of postglacial erosion are common.

\section{CHARACTERISTICS OF GLACIAL EROSION}

Of a very distinct type, however, are the channels of erosion which form the subject of this paper and which are glacial instead of postglacial in their origin.

The longer axes of the drumlins are closely parallel in direction with the glacial grooves upon the rock surfaces in their own neighborhood, as in the central part of the state they are both nearly north and south, while in the neighborhood of Boston they are about southeast.- The eskers, which are now generally believed to be formed by the accumulation of material in the bed of streams flowing on, in or under the ice-sheet, also agree fairly in direction with the above. This latter fact tends to show that the drainage of the glacial sheet was practically in the direction of its motion. So likewise these glacial stream channels with very few exceptions obey the same law and run southward. They cut the typical, symmetrical drumlin at all altitudes from the base to the exact summit ridge, and while winding as is usual with the course of a stream their general direction is parallel to the axis, though often they break through their lower bank and seek the shortest way down the steeper side to the bottom of the hill. Often they occur, passing

II -Bur.t. Grol. Soc. AM., Vol. 6, 1894. 
along the very summit axis, beginning sometimes far below the summit on the north end, cutting throngh the highest part on its way and continuing down the south slope to the base of the hill, its bed having a continuous southward slope from its first starting point. In a few cases, as at the hill south of Whittier's birthplace, in Haverhill, the channel passes along one side of the hill for some distance, then suddenly cuts transversely across its axis, and then passes southward along the opposite side. Some of the complex drumlins have a ridge-like form extending east and west or nearly so-sometimes divided on the summit by very shallow incipient valleys into separate summits - sometimes presenting no trace of such divisions. The erosion channels found on them may commence south of the east and west axis and slope down the south side, or they may begin on the north side one-half or more of the way up, cut through the axis and down the south side with a continuous south slope of the bed from its first appearance. The southward slope of the bed of the channel throughout its entire length is a marked characteristic, as it is very exceptional to find the northern portion of the bed sloping northward, though such cases do occur, as at Brown hill, east of Ayer Junction, and at North Leominster.

The same rule holds with the smaller channels, which, with rare exceptions, are found entirely upon the south slopes or on the southeast or southwest sides.

As an example for more detailed consideration, I have selected a drumlin having nearly the perfect typical form, which has a channel of moderate size nearly coincident with its longer axis for almost its entire length. This hill is situated in that part of the town of Stow known as Rockbottom, a region where drumlins are fairly numerous, there being from twenty-five to thirty within a radius of five miles. The Assabet river flows through this group, winding in curves of a mile or more in radius, but nowhere cutting into any portion of them nor having ever exerted an erosive power upon them. Directly north of the hill selected for detailed study and just across the river are two hills of the same elevation it has. One of them is a typical drumlin; the other an irregular mass of till. Within a third of a mile to the northeast and east, there are two more of similar character.

Southward about a quarter of a mile is a broad, flat mass of till, over which passes an esker, of which more will be said. Immediately to the west or slightly southwest is a nearly typical drumlin so closely connected with the one under discussion that the valley between the two is elevated one-half the height of the hills above the general level of the country.

The altitude of the bottom lands along the course of the river is 200 feet above sea-level, and above them the hill given on the map as Orchard hill, but known locally as Gleason's hill, rises about 100 feet, making its altitude above the sea 300 feet. It has a length of about half a mile and a width about one-half as great. As seen at a little distance from the east, it presents the smooth, graceful outlines of the ordinary type, except that it has a long, gentle slope to the south and a much steeper one to the north.

Ascending the type drumlin from the east to the line of the axial summit, a deep channel is found, which, from its winding, tortuous form, conveys the impression that it is a deserted water-course. Beginning at the north end of the hill, at an elevationn of about three-fourths its height, or 75 feet, it passes directly along the axis down the south slope, a distance of 2,000 or more feet, to the base. The bed has a southward slope throughout its entire course, except for a few feet at the north end, where the slope is northward. The greatest depth of the channel, 27 
feet, is at the point where it cuts the highest portion of the hill, and south of that the slope of the bed is gentle-a little less than that of the hill itself-until it reaches the base.

A few rods south of the deepest point the depth is 26 feet, while at the same distance north it is but $17 \frac{1}{2}$ feet. In each case these depths are taken from a line connecting the crests on each side, that on the west being always slightly lower-two or three feet-than that on the east.

At one point the bed is $3 \frac{2}{3}$ feet higher than at a point some hundred feet farther up stream, but this is a common feature in the beds of streams with considerable slope. The greater depth at the latter point coincides with a bend of the stream that would produce greater velocity and a deeper erosion.

The bed is nearly free from bowlders, as, is also the surface of the hill. This absence can be accounted for by the numerous stone walls in the construction of which all superficial stones have been used. A section of the interior of the hill has been exposed on the east side by sinking a well 12 feet in diameter and 50 feet in depth. The material excavated was a compact blue till, containing only a smal number of stones, not exceeding one or two feet in diameter, most of which were well glaciated. The small number here present would also indicate that but few would be left by erosion in the bed of the stream.

The outline of the hill, exclusive of the channel, indicates that it had been formed as a symmetrical, well shaped drumlin, and that in this completely formed hill erosion has taken place by some means directly along its axis.

\section{Origin of the Channels}

Now, by what means and at what time was the action of a stream of water inaugurated at this elevation above the general level? It is necessary to suppose that at the time the stream came in contact with the north end of the hill it must have been flowing at an altitude as high or higher than that point. As this end of the hill is symmetrical below the channel and shows but slight, irregular indications of erosion, there must have been some material occupying this region to form a bed for the stream whose disappearance has left no visible trace. The only conceivable material that could so disappear is ice. Hence, at the time the channel wâs eroded, the ice-sheet must have lain to the northward, with a thickness exceeding the height of the hill and so impacted upon its northern slope that no current could pass downward in that direction. The stream, flowing over an ice-bed, came directly in contact with the summit of the hill, and thence onward eroded its channel in till to the base of the hill, where it lost its cutting power, and deposition ensued. Before reaching the hill the stream may have been superglacial or englacial. It could not have been subglacial ; but from this point it may have been subglacial, as the ice-sheet may not have then entirely disappeared to the southward, or it may have entirely disappeared in that direction and the stream have thence been open to the sky.

Just at the bottom of the hill, in the broad mouth of the channel, is an eskerlike ridge of a few rods in length, while the valley between this and the hill to the south is filled with kame material, some of which may have come from this source

Over the irregular mass of till to the south and in line with this channel winds an esker as a broad, flat ridge; but on the south slope the esker is replaced by a 
narrow, sharp channel. In the valley south of this there is no indication of an esker; but, passing over the next elevation of till, a large mass divided into three summits, there are indications of erosion in the main valley, and then on the south slope there is a cirque-like hollow, which appears to have been excavated by a fall of water, as in a moulin. From the mouth of this runs an esker, having a height varying from 4 or 5 to 30 feet, which continues for a half mile, except where cut by a brook. With a few breaks, a line of eskers can be traced in this same linear direction as far as Hopkinton, a distance of ten or more miles. This shows a general line of glacial drainage to have existed in this direction. Directly north of Gleason's hill no eskers have as yet been found, though prominent ones exist both to the northwest and northeast.

At North Leominster, directly east of the station, is a large mass of till, which forms a common base, upon which rest some ten or eleven summits of various degrees of perfection. The largest channel yet seen is eroded out of the west end of this mass. The depth of this channel has not yet been measured, but it is probably between 80 and 100 feet. The width is correspondingly great, as the sides have not a very steep inclination. Here the amount of the material eroded is very large, yet so far no evidence has been found of its deposition elsewhere. The mouth of the channel opens directly toward the Nashir river, which is but a short distance away. It is probable that the detritus was carried into the floods which then filled the valley and by them was swept away, to be deposited farther down stream. This channel rises in a depression at the summit of the till mass and flows southward with a winding and gradually broadening course. The inclination of the bed is greater than that at Rockbottom. From the north side of the same depression from which this has its origin another passed down the north side, but this is more valley-like in appearance and has much less the characteristics of an erosional form. In this case no eskers seem to be connected with the channels.

Northwest of Worcester are three drumlins, not in direct line, each of which is cut by a channel and between each two of which are portions of eskers so arranged that the channels and eskers together form a nearly continuous serpentine line. The evidence seems to imply some kind of a connection in the origin of the esker and these channels. May not the same stream that produced the esker in one place have cut the channel in another? If a stream, either superglacial or englacial, were flowing on an ice-bed, material would accumulate in portions of its bed which subsequently formed the esker, but finding a mass of till, a more resistant material, in its course the action becomes then one of erosion instead of deposition, a channel is cut, and later, as the ice disappears, the esker is left in relief north and south of the channel, which is a representative of the same force.

About 300 channels of various sizes have been noted, but only in a few cases has time allowed for more than a hasty glance at each. As stated above, only a very small per cent of this number slope to the north; it is necessary to suppose in all these cases, as in the one at Rockbottom, that the ice-sheet lay pressed against the north side or end. What may have been the condition to the south is difficult to determine. It may have been that there the ice had entirely melted and that the front of the sheet was at the north of the hill, or it may be that melting had taken place directly over the southern slope of the hill, and that here the stream simply passed below the ice surface to become subglacial. Possibly further observations may clear up this point. 
In conclusion, I wish to state that Professor Shaler called my attention during the early part of my work to a channel on Forbes hill, in Milton, which he had previously observed and to which he had ascribed a somewhat similar origin.

Following the reading of Mr Barton's paper the Society adjourned. No evening session was held.

\section{Session of Wednesday, August 15}

The Society was called to order at 9.15 o'clock a m.

Matters of business were deferred to a later hour of the session and the reading of scientific papers was resumed. The first paper was-

TRIAS AND JURA OF SHASTA COUNTY, CALIFORNIA

BY JAMES PERRIN SMITH

Remarks were made by H.S. Williams.

The next two papers were not on the printed program, being offered late, but were presented by their authors:

GEOLOGICAL AGE OF THE MANGANESE DEPOSITS OF THE BATESVILLE REGION, ARKANSAS

BY H. s. WILLIAMs

The paper was discussed by J. F. Kemp, Jed Hotchkiss and J. P. Smith.

REPORT ON THE PROGRESS IN GEOLOGY DURING THE PERIOD BETWEEN THE CENTENNIAL AND COLUMBIAN EXPOSITIONS

BY JED HOTCHKISS

The matters of business were taken up.

The special committee appointed at the Madison meeting to consider and act upon the matter of making the Pacific Forest Reserve a national park presented the following report:

REPORT OF THE MOUNT RAINIER PACIFIC FOREST RESERVE COMMITTEE

To the Geological Society of America :

At the Fifth Summer Meeting of the Society, held at Madison, Wisconsin, in August, 1893, a committee was appointed to take into consid- 
eration the matter of making the Mount Rainier Pacific Forest Reserve a national reserve, and the committee was given power to memorialize Congress or take such other measures as they deemed advisable. The committee as originally elected consisted of David T. Day, S. F. Emmons and Bailey Willis. Dr Day requested to be excused from service on the committee on account of his want of familiarity with the region in question. The duties have consequently devolred upon the other two members, who beg to submit the following report:

Committees for the above purpose had also been appointed by the American Association for the Advancement of Science, the National Geographic Society of Washington, the Sierra Club of. San Francisco and the Appalachian Club of Boston. Those members of either committee who happened to be in the city of Washington during the winter of 1893-'94 constituted a general committee, which held meetings from time to time, in conjunction with the representatives in Congress of the state of Washington, to consider and discuss the best methods of accomplishing the object desired.

Congress has of late show's some reluctance to create new national parks on account of the expense involved and because of the opposition of those who might desire to take up the lands thus reserved. In preparing the bill and accompanying memorial it was therefore necessary to use circumspection in order to avoid any possible opposition. The labor of preparing these papers has largely fallen on the members of your committee, who happened to be the members of the general committee most familiar with the geography of the region around mount Rainier.

A copy of the bill and memorial* which were submitted to the action of Congress by Senator W. C. Squire is enclosed herewith. From the map accompanying the latter, which was prepared by Mr Willis from the latest available data, it will be observed that the area of the proposed national park does not include the eastern half and extreme northern and southern edges of the forest reservation. Some of the citizens of the state of Washington consider these portions of possible value for mining or railroad purposes, and it was feared their opposition might jeopardize the success of the measure. The area given does, however, include all the glaciers and the most important scenic features in the vicinity of mount Rainier.

The bill which was introduced on July 26 was referred to the Senate Committee on Public Lands, and will probably not be acted upon until

* Senate Mis. Doc. No 247, 53d Congress, $2 d$ session. See also the speech of Senator W. C. Squire, of the state of Washington, in laying the memorial before the Senate, July 26, 1804. 
the winter session of Congress. Senator Squire and the Honorable W. H. Doolittle, member of Congress from Washington, have shown great personal interest in the measure and will do their utmost to secure its passage. Your committee would suggest to any members of the Society who may be personally acquainted with members of either house of Congress to urge upon them the importance of reserving this unique and beautiful region for the public use.

Very respectfully submitted.

\section{S. F. EMmons, BaILEy WiLlis, Committee.}

The documents referred to in the report were noticed by the acting President. The map referred to had been copied upon the blackboard. Remarks were made by $\mathrm{W} \mathrm{J} \mathrm{McGee} \mathrm{in} \mathrm{response} \mathrm{to} \mathrm{questions.}$

It was voted to accept the report, with the thanks of the Society, and to continue the committee.

\section{PROPOSED AMENDMENTS TO THE CONSTITUTION}

The Secretary announced that the Council would again submit to the Society the following proposed changes in the constitution :

To amend article iii, section 1, by omitting the closing words of the section, "and resident in North America," so that the section shall read: "1. Fellows shall be persons who are engaged in geological work or in teaching geology."

To amend article iv, section 8, by inserting after the word "Editor" the words "and Treasurer," so that the paragraph shall read: "The Secretary, Editor and Treasurer shall be eligible to reëlection without limitation."

\section{PROPOSED AMENDMENT TO THE BY-LAWS}

The Secretary also stated that the Council recommended the following change in the By-Laws:

To amend chapter VII, section 1, by omitting the words "of moneys paid by the general public for publications of the Society," so that the section shall read: "1. The Publication Fund shall consist of donations made in aid of publication and of the sums paid in commutation of dues, according to the By-Laws, chapter I, clause 2."

The Council also announced, through the Secretary, that on account of the depleted condition of the treasury it would not be possible to print many of the papers read at this meeting, and a close selection would be necessary. 
The presentation of papers was resumed, and the following three papers were read by title:

PROCESS OF SEGREGATION AS ILL USTRATED IN THE NEW JERSEY HIQHLANDS BY RALPH s. TARR

ALUNOGEN AND BAUXITE OF NEW MEXICO, WITH NOTES ON THE GEOLOGY OF THE UPPER GILA REGION

BY WILLIAM P. BLAKE

USE OF THE ANEROID BAROMETER IN GEOLOGICAL SURVEYING

BY CHARLES W. ROLFE

The following paper was read by the author:

PLATYCNEMIC MAN IN NEW YORK

BY WILL H. SHERZER

The following three papers were read by title:

OIL AND GAS IN RA NSAS

BY ERASMUS HAWORTH

FAULTS OF THE REGION BETWEEN THE MOHAWK RIVER AND THE ADIRONDACK MOUNTAINS

BY N. H. DARTON

THE DRUMLINOID HILLS NEAR CAYUGA, NEW YORK

BY RALPH S. TARE

The following paper was presented in abstract by J. P. Smith:

REVIEW OF OUR KNOWLEDGE OF THE GEOLOGY OF THE CALIFORNIA COAST RANGES

BY HAROLD W. FAIRBANKS

This paper is printed in full in this volume.

The following three papers were read by title:

GEOLOGICAL HISTORY OF MISSOURI

BY ARTHUR WINSIOW 
THE MAGNESIAN SERIES OF THE NORTHWESTERN STATES

BY C. W. HALL AND F. W. SARDESON

This paper, which was read at the Madison meeting and was to have been printed in volume $5, *$ will be printed in full in this volume.

STRATIGRAPHY OF THE SAINT LOUIS AND WARSA W FORMATIONS IN SOUTH EASTERN IOWA

BY CHARLES H. GORDON

In the absence of the author, the following paper was presented in abstract by H. S. Williams :

KANSAS RIVER SECTION OF THE PERMO-CARBONIFEROUS AND PERMIAN ROCKS OF KANSAS

BY CHARLES S. PROSSER

This paper is printed in full in this volume.

The following paper was read by title:

CENOZOIC HISTORY OF A PORTION OF THE MIDDLE ATLANTIC SLOPE

BY N. H. DARTON

In the absence of the author, the next paper was presented in abstract by G. H. Barton.

TERTIARY AND EARLY QUATERNARY BASELEVELING IN MINNESOTA, MANITOBA, AND NORTHWESTWARD

BY WARREN UPHAM

[Abstract]

Contents

Baseleveling of the Cretaceous northwestern plains during the Tertiary era.... Page

Areal and vertical extent of the baseleveling................................................................ 18

Renewed elevation and partial baseleveling at the close of the Tertiary and during the early

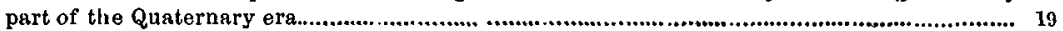

Relationship of the later baseleveling to the Ice age........................................................... 20

Baseleyeling of the Cretaceous northwestern Plains during the Tertiary Era.

From the valleys of the Mississippi and Minnesota rivers, the Red river of the North, and lake Winnipeg, a broad area of plains ascends gradually westward to the foot of the front ranges of the Rocky mountains. The first ascent from the

* See volume 5, page 7 .

III-Bult. Grot, Soc. Am., Voz. 8, 1894. 
Minnesota and Red river valleys and from the flat country inclosing lakes Winnipeg, Manitoba, and Winnipegosis, is mainly by an abrupt escarpment eroded in the Cretaceous strata forming the eastern border of the plains. The altitude of these valleys and of the Manitoba lake region ranges from 1,000 to 750 feet above the sea, and the escarpment, which, as viewed from the lowlands on the east, is named in its successive portions from south to north the Coteau des Prairies, the Pembina, Riding and Duck mountains, and the Porcupine and Pasquia hills or mountains, rises from 200 or 300 feet to 1,000 feet within a few miles. its crest being mostly 1,500 to 2,000 feet above the sea-level. Thence westward the expanse of the plains, broken here and there by eroded valleys and tracts of sometimes very irregular denudation, has nevertheless for the greater part a very uniform nearly flat or moderately rolling surface, which rises on the average four or five feet per mile to a height somewhat exceeding 4,000 feet above the sea at the foot of the Rocky mountains in Montana and Alberta, on the opposite sides of the United States and Canadian international boundary.

The geologic strata of this northern part of the great plains are the Dakota, Colorado, Montana and Laramie formations of late Cretaceous age, whose deposition took place during the closing part of the Secondary or Mesozoic era. Since the beginning of the Tertiary era this region has been a land surface undergoing denudation. When its marine and lacustrine deposits were first raised to be dry land they had a monotonously flat surface. A very long cycle of baseleveling ensued, beginning as soon as this northern part of the plains was uplifted at the end of Cretaceous time and continuing nearly or quite to the end of the Tertiary era. During this time the surface was gradually lowered by the action of rains, rills, rivulets, creeks and rivers, until it was mostly reduced to a baselevel of subaërial erosion.

\section{Areal and vertical Extent of the Baseleveling.}

Across an area 700 or 800 miles wide from east to west on the international boundary and of much greater extent from south to north the processes of baseleveling were at work through the vast duration of Tertiary time; but here and there isolated areas of hills and even mountains remain, consisting of remnants of the horizontal Cretaceous strata which elsewhere have suffered erosion. The most noteworthy eastern highland area of this kind is the Turtle mountain, lying in the north edge of North Dakota and the south edge of Manitoba, its extent on the boundary being about 40 miles, with two-thirds as great width. Its altitude above the surrounding country is 300 to 800 feet, the summits of its highest hills being about 2,500 feet above the sea. Beneath a veneering of glacial drift, which is in large part morainic and generally strewn with many bowlders, averaging perhaps 50 to 75 feet in thickness, Turtle mountain consists of nearly horizontally bedded Laramie strata, chiefly shales, with very thin seams of lignite. At or below the base of this highland the fresh-water Laramie formation rests on the marine series, which comprises the Fox Hills sandstone and Fort Pierre shales, the two great shale formations being separated by a sandstone stratum which outcrops in North Dakota on Ox creek and Willow river and on the Souris river between Minot and its most southern bend. A thickness of not less than 500 to 1,000 feet of the Lara, mie and Montana (Fox Hills and Fort Pierre) strata has been carried away from the surrounding eastern part of the plains. 
Westward the depth of the Tertiary baseleveling was greater. Around the Highwood and Crazy mountains, in central Montana, according to Professor W. M. Davis * and Dr J. E. Wolff, $†$ the erosion of the plains has a vertical extent of 3,000 to 5,000 feet. Perhaps the most striking evidence of this great erosion is afforded by the range of the Crazy mountains, which lies immediately north of the Yellowstone river near livingston and is conspicuously seen from the Northern Pacific railroad. These mountains trend slightly west of north, and extend about 40 miles with a width of 15 miles, attaining an elevation of 11,178 feet above the sea and 5,000 to 6,000 feet above the prairies at their base. Their structure has been thor oughly studied by Wolff, who finds that they consist of late Cretaceous strata, soft sandstones, nearly horizontal in stratification, intersected by a network of eruptive dikes. The more enduring igneous rocks have preserved this range, while an average denudation of not less than one mile in vertical amount reduced all the adjoining region to a baselevel of erosion. The Highwood mountains, about 25 miles east of Great Falls, having a height of 7,600 feet above the sea or about 3,000 feet above their base, are described by Davis as displaying the same structure, and therefore similarly testifying of great denudation.

The uplift at the beginning of the Tertiary era appears to have raised this portion of the plains to a height above the sea as great as the vertical extent of their Tertiary erosion-that is, to a height of at least 1,000 to 5,000 feet, increasing from east to west. Toward the end of this era the baseleveling had reduced the country mostly to a plain, which was probably only a few hundred feet above the sea, lying much below its present altitude.

\section{Renewed Elevation and partial Baseleveling at the Close of the Tertiary and during the farly Part of the Quaternary Era.}

Between the general Tertiary cycle of baseleveling and the Glacial period there ntervened a second great epeirogenic uplift, as shown by a return of the conditions of vigorous stream erosion and a new cycle of partial baseleveling, by which wide flat valleys were cut in the eastern part of these Cretaceous plains. In Manitoba the northeastern border of the formerly baseleveled expanse was removed, the Cretaceous beds being eroded to the underlying Archean and Paleozoic rocks upon a large area bounded on the west by the escarpment before mentioned as forning the eastern limit of the plains. The duration of the earlier baseleveling apparently coincided as to both beginning and end with the Tertiary or Somerville cycle of partial baseleveling which Davis and Wood have studied in Pennsylvania and northern New Jersey and believe to have affected a large area of the other eastern states. $\neq$

East from the foot of the Pembina, Riding and Duck mountains and the hills farther north, together called the Manitoba escarpment by Mr J. B. Tyrrell, of the Canadian Geological Survey, Cretaceous strata have not been found, so far as I have learned, in Manitoba, nor in the region north and northeast from lake Winnipeg to Hudson bay. It seems quite certain, however, that Cretaceous beds continuous from this escarpment extended eastward at the end of the Tertiary base-

* Mining industries of the United States, Tenth Census, vol. $x$ v, pp. 710, 737, 745.

† Bulletin, Geol. Society of America, vol. sii, 1892, pp. 445-452.

‡ Proceedings Boston Society of Natural History, vol. xxiv, 1889. pp. 365-423; National Geographic Magazine, vol. i, 1889, pp 183-253; vol. ii, 1890, pp. 81-110. 
leveling so far as to cover the area of lake Winnipeg. As Hind and Dawson have well pointed out, it was by the erosion of the eastern portion of these beds, after the great western expanse of the plains had received nearly its present form, that this steep escarpment was produced.* At the time of uplifting of the plains, near the beginning of the Quaternary era, this great baseleveled region appears to have stretched from the Rocky mountains to the Archean hills on the eastern border of the area of the later glacial lake Agassiz. The east margin of the soft Cretaceous strata was then anew subjected to rapid erosion, with the result that it was almost wholly worn away to the floor of Archean gneiss and granite and the Paleozoic limestones upon a width of 100 miles or more and to a depth westward of 300 to 1,000 feet, as shown by the height of the Pembina mountain and Manitoba escarpment.

In Minnesota and North Dakota the flat Red river valley plain, averaging 50 miles wide, with a depth of 200 to 500 feet below the country on each side, and extending more than 200 miles from south to north, opening into the Manitoba lake area, appears also to have been eroded at the same time. The conspicuous Pembina mountain escarpment of Cretaceous shales, overspread by drift, on the west side of this valley, deep wells penetrating through the drift to Cretaceous beds and older strata along the low valley plain, and the topographic features of the land rising eastward from it, with nearly the same rate of ascent as on the west, lead to the belief that the eastern, like the western, border of this wide valley is formed by an escarpment of Cretaceous shales beneath the drift. The baseleveled plain of the Tertiary era has been broadly and deeply channeled during a later time of high continental uplift.

\section{Relationship of the later Baseleveling to the Ice Age.}

Flowing so great distances before reaching the sea, the rivers of both these cycles of baseleveling may have denuded their areas of drainage, during the first cycle very completely and during the second partially, to broad plains, while yet the altitude of the Manitoba lake region equaled or exceeded that of the present time. Lake Winnipeg is 710 feet and lake Manitoba 809 feet above the sea. Newly uplifted as a high plateau during the early portion of the Quaternary era, this north part of the continent, rising probably somewhat faster in the Arctic region than farther south, may have continued to present favorable conditions for the baseleveling of the Red river valley and the district of the great Manitoba lakes until the mean altitude of the area which became covered by the North American ice-sheet and its drift was 3,000 to 5,000 feet higher than now, as indicated by the fjords and submarine valleys of our northern Atlantic, Arctic and northern Pacific coasts. The culmination of this uplift appears to have brought such cold and snowy climate that a vast sheet of snow and ice was gradually accumulated, under whose weight the land finally sank mostly somewhat below its present height, causing the icesheet to be melted away, with deposition of its glacial and modified drift.

This paper is published in full in the American Geologist, vol. xiv, October, 1894, pp. 235-246.

* H. Y. Hind, Report of the Assiniboine and Saskatchewan Exploring Expedition, Toronto, 1859, pp. 168, 169 ; Narrative of the Canadian Exploring Expeditions, London, 1860, vol. ii, pp. 48, 55, 265. G. M. Dawson, Geology and Resources of the Forty.ninth Parallel, 1875, pp. 253, 254. 
The next paper, by the same author, was read by title:

DEPARTURE OF THE ICE-SHEET FROM THE LA URENTIAN LAKES

BY WARREX UPHAM

[Abstract]

Contents

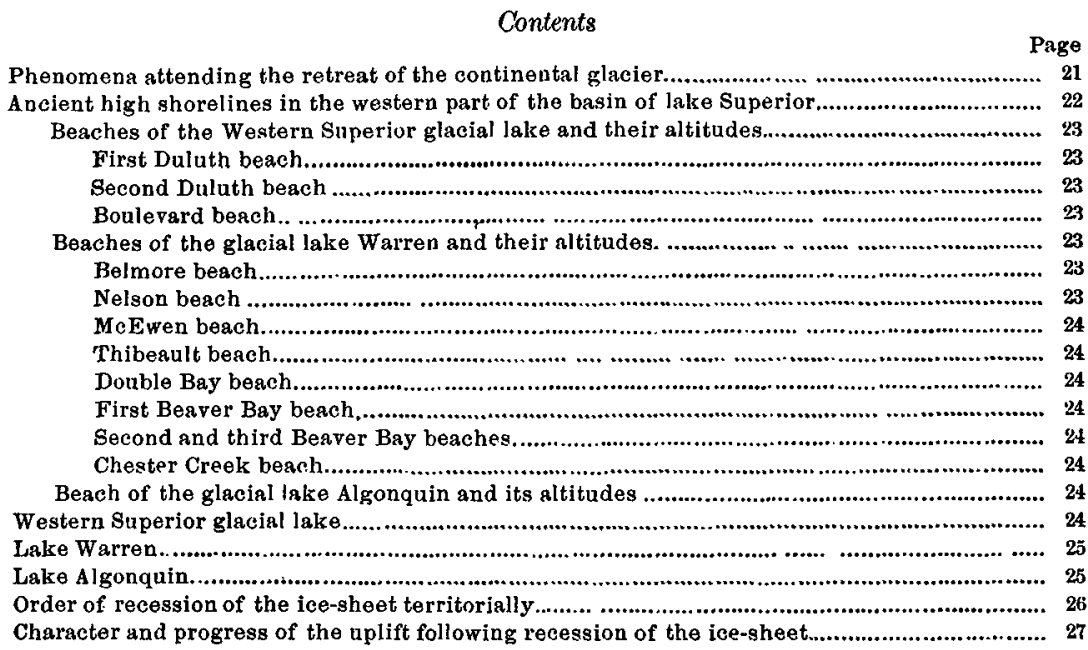

Phenomena atpending the Retreat of the continental Glacher.

The glacial drift reveals to us far more of the history of the Champlain epoch or time of general retreat of the ice-sheet with deposition of its drift and accumulation of its retreatal moraines than all which we can learn concerning the oncoming and culmination of the Ice age. During this closing Champlain epoch of the Glacial period lakes of great extent, held in on their nortbern and northeastern or iceward sides by the barrier of the gradually waning and departing ice-sheet, existed in the valley of the Red river of the North and the basin of the great. lakes of Manitoba and in the basins of the Laurentian lakes, Superior, Michigan, Huron, Erie, Ontario and Champlain. The glacial lake Agassiz, attaining an area of more than 100,000 square miles, occupied the Red river valley and a large part of Manitoba, and the similar but smaller lakes Warren, Algonquin, Iroquois and HudsonChamplain, in part successive and in part contemporaneous with one another, filled the basins of the great lakes now outflowing by the Saint Lawrence, their ancient shorelines, with beaches and deltas, being much higher than the present lake levels. The uplift of the area of lake Agassiz was practically completed during the Champlain epoch or time of the glacial retreat, as is known by the horizontality of its lowest and latest beaches, whereas its highest and earliest shores have received an inclination of ascent northward averaging about one foot per mile along their observed extent of 400 miles.* In like manner, but with greater

*" Wavelike Progress of an Epeirogenic Uplift," Journal of Geology, vol. ii, pp. 383-395, MayJune, 1894. 
complexity, the shorelines of the glacial predecessors of the Laurentian lakes were uplifted with varying gradients, so that now, in connection with the history of the successive channels of outlet opened by the retreat of the ice, they record the wavelike northeastward advance of a permanent uplift of that region from its Glacial and Champlain depression.

Ancient high Shorelinfs in the western Part of the Basin of Lake Superior.

The upper limit of lacustrine action in Duluth and its vicinity, at the west end of lake Superior, is marked by discontinuous beach deposits on the upper part of the steeply ascending bluffs at an altitude of 535 to 540 feet above the lake. Another shore terrace of beach gravel and sand is at 515 to 505 feet, approximately. Next below these shorelines is the most definite and persistent beach of the entire series, both of the Western Superior lake and the ensuing lake Warren. This was generally represented along the bluff face by a narrow beach terrace or slight shelf carved and built up by the waves acting on the drift which thinly overlies the bed rock, less steep than the slopes below and above it, so that its contour line, 470 to 475 feet above the present lake, has been used as the course of a driveway, known as " the boulevard," which has been graded and is much used for pleasure driving, along an extent of four miles; above the principal part of the city of Duluth, from Millers creek to Chester creek. Beyond these limits the boulevard is planned to be extended for distances of four miles more both to the southwest and northeast, following the same altitude and shoreline, giving a total length of 12 miles. Its height is only a few feet above the water divide in the old channel of outflow from the Western Superior glacial lake past the head of the Bois Brule river to the Saint Croix river ;* but, if we make due allowance for the partial filling of that channel with postglacial alluvium and peaty swamp deposits, it seems probable that this latest shore of that glacial lake has now an ascent of 15 or 20 feet in the distance of about 25 miles from its outlet north-northwest to Duluth. The earlier and higher shores here were made when the erosion of the outlet lacked successively about 65 and 30 or 35 feet of its final depth; but a certain part of its earliest erosion had been done before the retreat of the ice extended the lake to this north west coast.

Between the neighborhood of Duluth and mount Josephine, on the north coast of lake Superior, near Grand Portage, no definite observations of these three early shorelines have been obtained, although there can be no doubt that they extend continvously along this distance, which is about 130 miles in a nearly direct northeastward course. 'When the woods of this high coast shall be cleared off, as will probably some time be done in many places for farming and pasturage, the old lake levels will be observed, especially the highest and lowest of these three noted at Duluth. Attempting to correlate these beaches with those found by $\mathrm{Dr}$ A. C. Lawson $\dagger$ on mount Josephine, I identify the 535 feet and 515 to 505 feet Duluth shores as representing his 607 and 587 feet shores; and the 475 to 470 feet beach of the Duluth boulevard becomes apparently the conspicuous 509 feet beach of mount Josephine. The total differential uplifting of the two upper shores between these localities has been about 70 feet, of which about half had been accomplished previous to the time of the Boulevard beach.

* Proc. Am. Assoc. Adv. Sci., vol. xxxii, for 1883, p. 230; Geology of Minnesota, vol. ii, 1888, p. 642 ; Bulletin Geol. Society of America, vol. i1, 1891, p. 258.

† Geol and Nal. Hist. Survey of Minnesota, Twentieth An. Rep., for 1891, pp. 251-253. 
Eight lower shorelines, formed after the Western Superior lake was merged with the more extensive lake Warren, are marked in and near Duluth by small beach ridges on portions of the old lake shores situated favorably for their accumulation, and by deltas of inflowing streams. A fine succession of these deltas was observed along the course of Chester creek, through the city of Duluth, in its descent from its high valley cut in the upper part of the bluffs. To present concisely the results of my studies for the Minnesota Geological Survey* of the whole series of lake shores observed by me in the vicinity of Duluth and their probable correlations with the shores observed farther eastward by $\operatorname{Dr}$ A. C. Lawson, $\nmid \mathrm{Mr}$ F. B. Taylor, $\ddagger$ Professor J. W. Spencer $\&$ and others, they are arranged a little farther on in their descending order, with notes of their altitudes at numerous places in feet above lake Superior. The observations along the north coast of this lake are by Dr Lawson; on Isle Royale and in part on the Keweenaw peninsula, by Dr A. C. Lane, from unpublished work for the Michigan Geological Survey; and along the southern coast of lake Superior, about Green bay of lake Michigan and eastward to lake Nipissing, by Mr Taylor. On northern portions of the lake Superior coast several of these old lake levels seem to be each represented by two or more shores, separated by vertical intervals of 10 feet or more. Most of the beaches, it should be remarked, are very feebly developed, even in the most favorable localities for their formation, and are not discernible along the greater part of all the lake borders.

BEACHES OF THE WESTERN SUPERTOR GLACIAL LAKE AND THEIR ALTTTUDES

First Duluth Beach. - At Duluth, 535 feet above lake Superior; on mount Josephine, 607 feet; at Kimball, Wis., 570 feet; and at L'Anse and Marquette; Mich., 590 feet.

Second Duluth Beach.-At Duluth, 515-510 feet; on mount Josephine, 587 feet.

Boulevard Beach.-At Duluth, 475-470 feet; on mount Josephine, 509 feet.

BEACHES OF THE GLACIAL LAKE WARREN AND THEIR ALTITUDES

Belmore Beach.-This name was given by Professor.N. H. Winchell to the corresponding earliest shoreline of lake Warren in Ohio. Near Wrenshall and in Duluth, 410-415 feet; Grand Portage, 440 feet; on the Kaministiquia river, 455 feet; at Mackenzie, on the Canadian Pacific railway 13 miles northeast of Port Arthur, Dr Lawson's descriptions indicate that this lake level, at about 475 feet, adjoined the melting ice-sheet (l. c., page 261) ; eight miles east of Cartier, about 600 ; southeast of lake Nipissing, 605-620. The Ridgeway beach of Professor Spencer.

Nelson Beach.-Named by Taylor in the vicinity of North Bay, lake Nipissing; probably united with the Belmore beach in Ohio and northward to Mackinac island. At Duluth, 385 feet; at Mackenzie, a morainic terrace, 420 feet; at Jackfish bay, 418 feet; at Cook's mill, north of Green bay, lake Michigan, 150 feet;

* Geol. and Nat. Hist. Survey of Minnesota, Twenty-second An. Rep., for 1893, pp. 54-66.

f "Sketch of the Coastal Topography of the North Side of Lake Superior, with special reference to the Abandoned Strands of Lake Warren," Minnesota Twentieth An. Rep., pp. 181-289, with plates, map and sections.

f "The Ancient Strait at Nipissing," Bulletin Geol. Society of Amarica, vol, v, pp. 620-626, April 1894; "Reconnaissances of the Abandoned Shorelines of Green Bay and of the South Coast of Lak $\theta$ Superior," Am. Geologist, vol. xiii, pp. 316-327 and 365-383, with maps, May and June, 1894.

8 Am. Jour. of Science, Dec., 1890, Jan. and March, 1891, and March, 1894; Bulletin Geol. Society of America, vol. ii, pp. 465-476, April, 1891. All thes $\theta$ articles are accompanied with maps. 
about the south part of this bay, nearly at the level of lake Superior; at Houghton, on the Keweenaw peninsula, 410 feet; Sault Ste. Marie, 414 feet; North bay, 538 feet.

McEwen Beach.-Named by Taylor near North Bay. At Duluth, 350 feet; Schreiber and Terrace bay, 391-2 feet; Sault Ste. Marie, 365 feet; North Bay, 488 feet.

Thibeault Beach.-Named also by Taylor near North Bay. Great Northern railway, about two and a half miles northeast of Foxboro, near the line between Minnesota and Wisconsin, 290-300 feet; mount Josephine, 313 feet; Mackenzie, 327 feet; Sault Ste. Marie, 311 feet.

Double Bay Beach.-At Duluth, 255-260 feet; at Double bay, 279 feet; on Isle Royale, about 270 feet; Carp river, 288 feet.

First Beaver Bay Beach.-At Duluth, 155-160 feet; at Beaver bay, 173 feet; eastward represented by two beaches: (a) at Grand Portage, 232 feet; at Carp river and Pie island, 222 feet; at Terrace bay, 243 feet; at Sault Ste. Marie, 224 feet; on the Keweenaw peninsula, 220 feet; (b) at Mazokamah, 214 feet; Terrace bay, 228 feet; Dog river, 216 feet; Sault Ste. Marie, 208 feet; on the Keweenaw peninsula, about 200 feet.

Second and third Beaver Bay Beaches.-Become three northeastward: At Duluth, 85-90 feet; Beaver bay, 126 and 115 feet; Pigeon river (third), 134 feet; Isle Royale, about 130 feet; shore above Carp river, 164, 128 and 122 feet; Port Arthur (third), 149 feet; Silver islet, 168,161 and 149 feet; Jackfish bay, 176 and 158 feet; Sault Ste. Marie, 150 feet; Keweenaw peninsula, 170, 150 and 145-125 feet (delta of Huron creek, A. C. Lane).

Chester Creek Beach.-At Duluth, 45-50 feet; Beaver bay, 80 feet; Isle Royale, 90 feet; McKellar's point, 101 feet; Port Arthur, 118 feet; Nipigon, 132 feet; Montreal river, 135 feet; Mackenzie, 122 feet.

BEACH OF THE GLACLAL LABE ALGONQUIN AND ITS ALTTTUDES

Lake Algonquin, and its highest shoreline, the Algonquin beach, which is here noted, were named by Professor J. W. Spencer.* At Duluth the Algonquin beach is united with the present lake beaches; at Beaver bay its height is 20 feet; Good Harbor bay, 27 feet; Grand Portage, 38 feet; McKellar's point, 48 feet ; Carp river, 52 feet; Pie island, 43 feet; Port Arthur, Nipigon and Montreal river, 61 feet; Houghton and Marquette, about 25 feet; Sault Ste. Marie, 49 feet; near Algoma, 60-80 feet; near North Bay, on lake Nipissing, 140 feet. The Nipissing beach of Mr Taylor, but not his "Algonquin beach" on Mackinac island, $\dagger$ which is the highest of the lake Warren shores, being apparently the compound representative of the Belmore and Nelson beaches.

\section{Western Superior glacial Lake}

The front of the departing ice-sheet was the barrier of the Western Superior glacial lake, while the one receded and the other advanced from Duluth northeastward to mount Josephine and the most northeastern point of Minnesota and eastward to Marquette. When the farther glacial recession opened the space for this lake and the similarly expanding lake Warren to be merged together above the

* Proc. Am. Assoc. Adv. Sci.. vol. xxxvii, 1888, p. 199.

t Am. Jour. Soi., III, vol. xliii, Mareh, 1892, pp. 210-218. 
low land of the eastern part of the Michigan upper peninsula, the Western Superior waters fell 50 feet or more below their former outlet to the Saint Croix and Mississippi rivers, and thenceforward the outlet of lake Warren past Chicago to the Mississippi, by way of the Des Plaines and Illinois rivers, carried away the drainage from the glacial melting and rainfall of the lake Superior basin.

\section{LAKE WARREN}

At a time that was probably somewhat later than the end of the Western Superior lake, its analogue, the Western Erie glacial lake, which had outflowed past Fort Wayne, Indiana, to the Wabash, Ohio and Mississippi rivers, became likewise lowered and merged in lake Warren, which in its soon ensuing maximum stage stretched from the south end of lake Michigan to the north side of lake Superior, northeast to Iake Nipissing, and eastward to the east end of lake Erie and the southwestern limits of the lake Ontario basin. The river outflowing from lake Warren probably cut down its channel 50 feet or more into drift which had been deposited in the rock valley of the Des Plaines river in the vicinity of Willow Springs and Lemont, between 15 and 30 miles southwest of Chicago. The month of the lake was thus reduced in height and transferred upstream, until, at the end of the duration of this outflow and of the glacial lake Warren, the drift-covered divide in the old channel, situated near Summit and the elbow of the Des Plaines, about 10 miles south west from the shore of lake Michtgan at Chicago,* was only seven or eight feet above the present mean lake level. While the outlet continued here, all the northern part of the area of lake Warren, extending about 600 miles from Duluth to lake Nipissing, was uplifted about 350 to 400 feet.

\section{LAKe ALgonguin}

When the glacial melting and retreat at length permitted an outflow from the Saint Lawrence basin over a lower pass, which was through central New York to the Mohawk and Hudson, the water surface in the basins of lakes Michigan, Huron and Superior fell only som $\epsilon 5$ or 75 feet from the latest and lowest stage of lake Warren to its short-lived successor, lake Algonquin: This lake was ice-dammed only at low places on its east end, as at or near the heads of the Trent and Mattawa rivers, lying respectively east of lakes Simcoe and Nipissing, where otherwise its waters must have been somewhat further lowered to outflow by those passes. A careful study of the late glacial or Champlain epeirogenic uplifting of all portions of the Saint Lawrence drainage area, as known by the present inclinations of its many shorelines, convinces me that Gilbert $\dagger$ and Wright $\ddagger$ have overestimated the importance of the outflow, if any such took place, from lake Algonquin past the present lake Nipissing to the Mattawa and Ottawa rivers. Professor Spencer's Algonquin beach is very clearly the Nipissing beach of $\mathrm{Mr}$ Taylor, and this earliets

\footnotetext{
* For information concerning this locality, and for a map and profiles of the canal now being constructed past it with continuous descent away from the lake, I am indebted to Mr Ossian Guthrie, of Chicago, who has bestowed much study on the glacial drift and Pleistocene history of that region.

+ "History of the Niagara River," Sixth An. Rep. of the Commissicners of the State Reservation at Niagara, for the year 1889, pp. 01-84, with eight plates (also in the Smithsonian Annual Report for 1890 ).

$\ddagger$ Bulletin Geol. Society of America, vol. iv, 1893, 423-427.
}

IV-Bur.t. Grot., Soc. Aw., Vor. 6, 1894. 
and principal stage of lake Algonquin is shown by these beaches to have coincided closely in area with lakes Michigan and Superior, but to have been considerably more extensive eastward than the present lake Huron and Georgian bay. It held a level which now by subsequent differential epeirogenic movements is left probably wholly below the level of lake Michigan by a vertical amount ranging from almost nothing to about 40 feet. Its shores were nearly coincident with the western shore of lake Huron, but eastward they are now elevated mostly 150 to 200 feet above that lake and Georgian bay, and in the lake Superior basin they vary from about 50 feet above lake Superior at its mouth and along its northeastern and northern shores to 25 feet at Houghton, and to a few feet or none at Duluth. The earliest outflow of lake A]gonquin appears to have passed southward by the present course of the Saint Clair and Detroit rivers; thence it ran east as a glacial river Erie, following the lower part of the bed of the present lake Erie, which then had an eastward descent of probably 200 feet, allowing no lake or oniy a very small one to exist in the deepest depression of the basin; and north of Buffalo it coincided with the course of the Niagara river.

\section{OrDer of Recession of the ICE-Sheet terRitorially}

The recession of the ice-sheet from the area of lakes Warren and Algonquin was earlier than from the lake Ontario or Iroquois basin and the country eastward to the New England coast.

During the time of formation of the high Belmore and Nelson beaches of lake Warren, this glacial lake, outflowing at Chicago, stretched northward to the north side of lake Superior and northeastward to lake Nipissing. With lake Warren of this extent, the ice-sheet had melted off from all the northern United States west of lake Nipissing and of Buffalo, New York ; but yet, to form a barrier on the east, it remained unmelted upon all the Niagara and lake Ontario or Iroquois area. Thus we see that all the moraines within the limits of the United States west of the great angle of the drift boundary near Salamanca, in southwestern New York, ${ }^{*}$ are somewhat older than the moraines east of that angle in New York, Pennsylvania, New Jersey, Long island and New England. This difference in age, however, between the western and eastern moraines and drift was perhaps no more than 500 to 1,000 years, as we may infer from the rate of retreat of the portion of the icefront forming the northern barrier of the glacial lake Agassiz.

This unexpected view of the order of departure of the ice-sheet finds meteorologic explanation as follows: The melting of the vast western part of the ice-sheet in the United States, from North Dakota and Minnesota east to the lake Erie basin, would supply to our eastwardly moving storms a very great amount of moisture to be precipitated farther east. That precipitation I think to have been mainly snow, as these storms, moisture-laden from the western ice-melting, swept over the more eastern part of the ice-sheet. Hence the eastern great ice-lobe from Salamanca to Long island, Cape Cod, and the gulf of Maine, would be fed and thickened and spread in some places even beyond its previous limits, while all of the ice-sheet farther west, in the United States was being melted away. $\dagger$

\footnotetext{
* Consult Professor Chamberlin's maps of the glaciated areas of the United States, U. S. Geol. Survey, Third Annual Report. plates xxviii and xxxiii; Seventh An. Rep., plate viii.

f For evidence of similar but smaller elimatic effects on the waning ice-sheet in Minnesota see Proc. Am. Assoc. Adv. Sei., vol. xxxii, for 1883, pp. 23!-234, and Geology of Minnesota, vol. ii, 1888, pp. 254-256, 409-413.
} 
Character and Progress of the Uplift following Rechsion of the Ice-sheet

A wave-like uplift from the Champlain subsidence advanced to the area of lakes Iroquois and Hudson-Champlain after it was nearly or quite completed in the area of lake Warren.

In previous discussions of the relationships of these glacial lakes * I have stated more fully than can be attempted in this paper the stages of advance of the gradual upward movement of their areas in its progress from south to north and from southwest to northeast; pari passu with the recession of the ice-sheet in the same directions. Closely following the ice-border in its retreat, there ensued an uplift of the northern part of the region covered by lake Warren to a total amount of 400 to 600 feet, of which the greater part, ranging from seven-eighths of the whole 400 feet at Duluth to about two-thirds of the whole 600 feet at lake Nipissing, had taken place before the time of the Algonquin or Nipissing beach. The continuation of this uplift during the time of accumulation of the lower beaches of lake Algonquin probably raised the area of the watershed between lake Nipissing and the Mattawa river to so great an altitude as to forbid outflow there previous to the removal of the ice harrier from the Mattawa and Ottawa basins on the east.

Like the uplift of the lake Agassiz area, first at the south, later in its central part, and latest at the north, so the region of the Laurentian lakes appears to have been elevated nearly or quite to its present level, first from Duluth east to lake Nipissing and Buffalo, and afterward, while the ice barrier of lake Iroquois was retreating, the basins of lakes Ontario and Champlain were raised approximately to their present altitude. The maximum gradient of the earlier part of the uplift of the Saint Lawrence basin was about five feet per mile from south to north upon portions of the Michigan upper peninsula ; and an equally large differential movement gave to the Iroquois beach an ascent of nearly 300 feet in 55 miles from south to north between Rome and the latitude of Watertown, New York. The correlative maximum northward uplifting of the shorelines of lake Agassiz is found by Mr J. B. Tyrrell along the eastern base of Riding and Duck mountains, in the north central portion of that lake's entire extent, being about three feet per mile. After the lake Iroquois area had received the greater part of its re-elevation from the Champlain subsidence, the more northern Ottawa and Saint Lawrence valleys were upraised to a maximum amount exceeding 500 feet at Montreal. From south to north and northeast a wave of epeirogenic upward movement advanced upon the region of the Laurentian lakes and to Montreal, nearly contemporaneous with the uplift of the valley of the Red river of the North, of Manitoba, and of the country thence northeast to Hudson bay.

The acting President declared the scientific program closed.

Professor Joseph Le Conte moved that the thanks of the Society be extended the trustees and officers of the Packer Institute for the use of rooms, and to the Local Committee of the American Association for the Advancement of Science for the preparations and facilities for the meeting. It was unanimously voted.

* Bulletin Geol. Society of America, vol. ii, 1890, pp. 258-265; vol. iii, 1891, pp. 484-487 and 608-511. 
Professor W. B. Scott asked permission to present the following-

NOTE ON FLORENTINO AMEGHINO'S LATEST PAPER ON PATAGONIAN PALEONTOLOGY

BY W. B. SCOTT

I desire to call attention briefly to Ameghino's latest paper, "Enumération synoptique des espèces de mammifères fossiles des formations Éocènes de Patagonie," Buenos Aires, 1894, that contains some very important facts for the estimation of the geologic age of the Patagonian Tertiary formations, which have yielded such an abundant and interesting mammalian fauna. The Santa Cruz bels are now proved to overlie the "Patagonian" beds instead of underlying them.

Ameghino still maintains the Eocene age of these beds, but European and North American paleontologists have repeatedly pointed out the modern character of their mammals and have referred them to the Miocene. The latter view is definitely confirmed by the occurrence of true whales (Balrena) in the "Patagonian" beds. The extraordinary isolation and peculiarity of this fauna offers few other terms for direct comparison with the Miocenes of the northern hemisphere.

The Sixth Summer Meeting was then declared adjourned.

\section{Register of the Brooklyn Summer Meeting}

The following Fellows were in attendance upon this meeting:

F. D. Adams.

G. H. Barton.

Samued Calvin.

B. K. Emerson.

H. I. Fairuhild.

A. E. Foote.

A. C. Gis.L.

C. H. Hı'сHCOCK.

C. A. Hollick.

JeD Hotchriss.

E. O. Hovey.

H. C. HoveY.

E. E. Howeld.

J. F. KEMP.

A. C. Lase.

Joseph Le Conte.

Florence Bascom.

D. F. LincolN.
W J MuGee.

F. J. H. MerRILL.

F. H. NEWELL.

W. N. Rice.

Heinrich Ries.

W. B. ScotT.

N. S. Shaler.

W. H. Sherzer.

J. P. SMITH.

J. W. Spencer.

J. J. Stevvenson.

A. S. Tiffany.

I. C. Whire.

R. P. Whitfinid.

H. S. WILLIAMS.

Fellows-elect

L. G. Westgate.

Total attendance, 34 . 